\title{
Duplex Real-Time Polymerase Chain Reaction Reveals Competition Between Erwinia amylovora and E. pyrifoliae on Pear Blossoms
}

\author{
Susan M. Lehman, Won-Sik Kim, Alan J. Castle, and Antonet M. Svircev
}

First, second, and fourth authors: Agriculture and Agri-Food Canada, Southern Crop Protection \& Food Research Centre, 4902 Victoria Ave. North, P.O. Box 6000, Vineland Station, ON, Canada LOR 2E0; and first and third authors: Department of Biological Science, Brock University, 500 Glenridge Avenue, St. Catharines, ON, Canada L2S 3A1.

Current address of second author: Norgen Biotek Corporation, 3430 Schmon Parkway, Thorold, ON, Canada, L2V 4 Y6.

Accepted for publication 7 February 2008.

\begin{abstract}
Lehman, S. M., Kim, W.-S., Castle, A. J., and Svircev, A. M. 2008. Duplex real-time polymerase chain reaction reveals competition between Erwinia amylovora and E. pyrifoliae on pear blossoms. Phytopathology 98:673-679.

Erwinia amylovora and E. pyrifoliae are the causative agents of fire blight and Asian pear blight, respectively. The pathogens are closely related, with overlapping host ranges. Data are unavailable on the current distribution of $E$. pyrifoliae and on the interaction between the two species when they are present together on the same host. In this study, a duplex real-time polymerase chain reaction (PCR) protocol was devel-

extraction. Primers and a probe based on the E. amylovora levansucrase gene detected all E. amylovora strains. All $E$. pyrifoliae strains, including the Japanese Erwinia strains previously described as E. amylovora, were detected with a primer and probe combination based on the E. pyrifoliae $h r p W$ gene. Disease development and severity were not significantly different in blossoms inoculated with individual Erwinia species or with a mixture of the two species. However, E. amylovora grew to greater population sizes than did E. pyrifoliae in both single species inoculations and in mixtures, suggesting that E. amylovora has a greater competitive fitness on Bartlett pear blossoms than E. pyrifoliae.
\end{abstract} oped to monitor the population dynamics of E. amylovora and E. pyrifoliae on the surface of Bartlett pear blossoms. Bacterial cells washed from blossoms were used directly as the PCR template without DNA
Additional keywords: bioassay, microbial population dynamics, multiplex detection, quantitative PCR, virulence.
Erwinia amylovora is well known as the causative agent of fire blight, a necrotic disease affecting species in the family Rosaceae. Fire blight was first described on apple trees in 1780 in the northeastern United States. The disease has since spread throughout much of North America, to New Zealand, England, most of Europe, and the Middle East (6). E. amylovora has a significant economic impact on commercial apple and pear crops. In the United States alone, fire blight is estimated to cost about $\$ 100$ million annually in crop loss and management costs (31). The annual disease cycle begins when E. amylovora is present in the orchard, usually in the margins of overwintering cankers from previous year's infections, and colonizes open blossoms in the spring (41). Under favorable temperature and moisture conditions, the E. amylovora population will grow and initiate new infections via natural openings in the blossom. Subsequent intercellular and intravascular growth of the pathogen leads to necrosis which can spread rapidly throughout the tree (41). Chemical and biological control methods are available to prevent initial infections, but once a tree is infected, the spread of the bacteria can only be stopped by cutting out infected tissue.

E. pyrifoliae Kim et al. (17), was isolated in the 1990s from Asian pear trees in South Korea that showed symptoms very similar to fire blight. The isolated organism had several morphological and biochemical characteristics in common with E. amylovora (34), and its 16S rRNA gene shared 99\% homology with the E. amylovora 16S rRNA gene (17). However, DNA:DNA hybridization data and the sequences of the $16 \mathrm{~S}-23 \mathrm{~S}$ intergenic transcribed spacer regions revealed the E. pyrifoliae isolates to be a

Corresponding author: A. M. Svircev; E-mail address: svirceva@agr.gc.ca

doi:10.1094/PHYTO-98-6-0673

(C) 2008 The American Phytopathological Society single species, distinct from E. amylovora (17). Additional molecular evidence for the distinction between $E$. pyrifoliae and $E$. amylovora has also been presented $(14,27,28)$. To date, E. pyrifoliae has only been isolated from Asian pear trees and has not been reported since the localized outbreaks in the 1990s (18).

Extensive work has been done to genetically characterize E. pyrifoliae, but except for some small-scale pathogenicity tests on apple and pear seedlings and immature pear fruit, the in vivo behavior of this organism has not been studied. Despite the genetic differences on which their classification is based, and differences in certain pathogenicity factors (20), both E. amylovora and E. pyrifoliae are pathogenic on both Asian and European pear varieties $(17,19)$. An understanding of how the two species interact when present together on an open blossom may shed light on their current distribution and on the potential for future spread of each organism.

Here, we describe the development of a duplex real-time polymerase chain reaction (PCR) protocol that permits simultaneous quantification of E. pyrifoliae and E. amylovora directly from plant samples. This approach is rapid and quantitative, and thus has advantages over previously described methods for differentiating E. amylovora and E. pyrifoliae using conventional PCR and gel electrophoresis (19). We then used this system to study the population dynamics of these two pathogens when present individually or together on the surface of Bartlett pear blossoms. In particular, we wanted to evaluate the potential for this tool to facilitate in situ studies of ecological relationships such as interspecies competition between bacteria in their natural environment.

\section{MATERIALS AND METHODS}

Bacterial strains and media. Strains of E. amylovora, E. pyrifoliae, Japanese Erwinia sp., Pantoea agglomerans (formerly 
Erwinia herbicola), E. carotovora, and Escherichia coli were grown on Difco nutrient agar. Pseudomonas strains were grown on NBY agar (37). All strains were incubated at $28^{\circ} \mathrm{C}$, except for E. coli, which was incubated at $37^{\circ} \mathrm{C}$. Bacteria used in these experiments are described in Table 1 . All listed strains were used for specificity testing of real-time PCR probes and primers. $E$. amylovora Ea6-4 and E. pyrifoliae Ep1/96 were used for competition assays.

Real-time PCR. E. amylovora- and E. pyrifoliae-specific primers and TaqMan probes were designed based on the levansucrase gene (GenBank X75079) and the hrpW gene (GenBank AY237642), respectively, by using web-based software provided by Integrated DNA Technologies (Coralville, IA). Candidate oligonucleotide designs were analyzed to ensure compatibility in a duplex reaction. Probe and primer sequences are listed in Table

TABLE 1. Bacterial strains used in this study

\begin{tabular}{lllc}
\hline Isolate & Host & Origin & $\begin{array}{c}\text { Source or } \\
\text { reference }\end{array}$ \\
\hline E. amylovora & & & \\
Ea6-4 & Pyrus sp. & Canada & $(10)$ \\
Ea1/79 & Cotoneaster sp. & Germany & $(8)$ \\
Ea321 & Crataegus oxyacantha & France & CFBP1367 \\
IH3-1 & Raphiolepis indica & USA & $(12)$ \\
IL5 & Rubus sp. & USA & $(29)$ \\
CA11 & Malus sp. & USA & $(7)$ \\
UTRJ2v & Malus sp. & USA & $(39)$ \\
Leb B66 & Malus sp. & Lebanon & $(35)$ \\
IVIA1614-2av & Crataegus sp. & Spain & $(24)$ \\
E. pyrifoliae & & & \\
Ep1/96 & Pyrus pyrifolia & Korea & $(17)$ \\
Ep2/97 & Pyrus pyrifolia & Korea & $(15)$ \\
Japanese Erwinia strains & & & \\
Ejp556 & Pyrus pyrifolia & Japan & $(18)$ \\
Ejp557 & Pyrus pyrifolia & Japan & $(18)$ \\
Ejp617 & Pyrus pyrifolia & Japan & $(18)$ \\
P. agglomerans & & & \\
Eh21-5 & Pyrus sp. & Canada & A. M. Svircev \\
C9-1 & Malus sp. & USA & $(13)^{\mathrm{x}}$ \\
E325 & Malus sp. & USA & $(33)^{\mathrm{x}}$ \\
E. carotovora Ecc26 & & & D. Cupples \\
E. coli DH-5 $\alpha$ & & & A. J. Castle \\
P. fluorescens A506 & & & $(22)^{\mathrm{x}}$ \\
P. syringae pv. & & & \\
papulans 4404 & & & A. M. Svircev \\
\hline
\end{tabular}

"Collection Française de Bactéries Phytopathogènes.

${ }^{\vee}$ Strains do not contain the pEA29 plasmid.

${ }^{w}$ Agriculture and Agri-Food Canada, Southern Crop Protection and Food Research Centre, Vineland Station, Canada.

x Pantoea agglomerans C9-1 and Pseudomonas fluorescens A506 are the active ingredients in commercial bacterial antagonists produced under the BlightBan7 label by Nufarm Americas Inc. (Burr Ridge, IL) for the control of fire blight. P. agglomerans E325 is the active ingredient in Bloomtime FD, a commercial bacterial antagonist produced by Northwest Agricultural Products (Pasco, WA) for similar use.

y Agriculture and Agri-Food Canada, Southern Crop Protection and Food Research Centre, London, Canada.

${ }^{\mathrm{z}}$ Department of Biological Sciences, Brock University, St. Catharines, Canada.
2. All primers and probes were synthesized by Integrated DNA Technologies.

Reactions were run in $25-\mu$ volumes using $1 \times$ ThermoPol PCR buffer (New England Biolabs, Ipswich, MA), $0.2 \mathrm{mM}$ each dTTP, dCTP, dATP, and dGTP, $2 \mathrm{mM} \mathrm{MgCl}_{2}, 0.1 \mathrm{mM}$ each probe, $0.2 \mathrm{mM}$ each primer, and $1.5 \mathrm{U}$ of Taq polymerase (New England Biolabs). Two microliters of the processed sample was used as the template in each reaction. Reactions were run in a Stratagene Mx4000 Multiplex Quantitative PCR system (La Jolla, CA) under the following conditions: $95^{\circ} \mathrm{C}$ for $5 \mathrm{~min}$; 40 cycles of $95^{\circ} \mathrm{C}$ for $10 \mathrm{~s}$ and $60^{\circ} \mathrm{C}$ for $16 \mathrm{~s}$, with two endpoint fluorescence readings during each amplification segment. Negative suspension buffer, and master mix-only controls were also included in each reaction cycle. Specificity tests were conducted in duplex reactions using the bacteria listed in Table 1 , singly and in mixtures.

Optimization of real-time PCR for quantitative analysis. Singleplex and duplex standard curves were constructed to allow quantification of each target organism. Fresh overnight plate cultures of E. amylovora Ea6-4 and E. pyrifoliae Ep1/96 were aseptically scraped from the plate surface and suspended in $0.01 \mathrm{M}$ sodium phosphate buffer, $\mathrm{pH} 6.8$, to a concentration of at least $1 \times$ $10^{9} \mathrm{CFU} / \mathrm{ml}\left(\mathrm{OD}_{600}=0.6\right)$ using a Beckman DU 640 spectrophotometer. The concentration of each suspension was calibrated by plating $100 \mu \mathrm{l}$ of serial dilutions in phosphate buffer and counting single colonies after 2 days. Templates for real-time PCR standard curves were prepared by serially diluting cell suspensions in clean blossom wash, either individually or as a mixture of both species. Standard curve construction was repeated using new bacterial cultures. PCRs were run in triplicate.

Competition assays. Bartlett pear shoots bearing dormant buds were harvested in late winter. Shoots were forced to bloom by placing them in water at $23^{\circ} \mathrm{C}$ in a well-lit room. Newly opened blossoms with yellow, undehisced anthers were harvested by hand and individually placed into scintillation vials such that the peduncle extended through a hole drilled in the lid and into the sterile tap water contained in the vial.

Suspensions of E. amylovora and E. pyrifoliae were prepared by aseptically scraping cells from fresh overnight cultures into $0.01 \mathrm{M}$ sodium phosphate buffer, $\mathrm{pH}$ 6.8. Suspensions were adjusted to $1 \times 10^{9} \mathrm{CFU} / \mathrm{ml}$, stored on ice, and further diluted in sodium phosphate buffer as needed immediately prior to application.

Ten microliters of a bacterial suspension was inoculated directly onto the hypanthium. Treatments were as follows: $0.01 \mathrm{M}$ sodium phosphate buffer, $\mathrm{pH} 6.8$ (negative control); $1 \times 10^{6} \mathrm{CFU}$ of either E. amylovora or E. pyrifoliae per blossom (positive control for virulence); $1 \times 10^{4} \mathrm{CFU}$ of E. amylovora or E. pyrifoliae per blossom or a 1:1 mixture of both for a total bacterial count of $1 \times 10^{4} \mathrm{CFU} /$ blossom; and $1 \times 10^{2} \mathrm{CFU}$ of E. amylovora or E. pyrifoliae per blossom or a 1:1 mixture of both for a total bacterial count of $1 \times 10^{2} \mathrm{CFU} / \mathrm{blossom}$. Each treatment was applied to 20 blossoms. Following inoculation, the blossoms were loosely sealed in large plastic bins containing about $500 \mathrm{ml}$ of water to maintain a high relative humidity and incubated at $23^{\circ} \mathrm{C}$.

TABLE 2. Sequences, product sizes, and targets of the forward primer (F), the reverse primer $(\mathrm{R})$, and the TaqMan7 probe (P) used for duplex detection and quantification of Erwinia amylovora (Ea) and E. pyrifoliae (Ep)

\begin{tabular}{lllc}
\hline Oligonucleotide & Sequence $\left(5^{\prime}\right.$ to $\left.3^{\prime}\right)$ & Position $^{\mathrm{y}}$ & Product size $^{\prime}$ \\
\hline Ea-lscF & CGCTAACAGCAGATCGCA & $345-362$ & 105 bp \\
Ea-lscR & AAATACGCGCACGACCAT & $449-432$ & \\
Ea-lscP & (CY5)CTGATAATCCGCAATTCCAGGATG(IAbRQ) ${ }^{\mathrm{z}}$ & $366-389$ & $756-773$ \\
Ep-hrpwF & CGCTAACCCGACTGTCT & $832-815$ & 77 bp \\
Ep-hrpwR & TGAAGGTTTCCCTTTGC & $776-799$ & \\
Ep-hrpwP & (FAM)ATGACACCATCATCGTAAAGGCGG(BHQ-1) & \\
\hline
\end{tabular}

${ }^{\mathrm{y}}$ Binding positions are based on GenBank files X75079 (lsc) and AY237642 ( $\left.h r p W\right)$.

${ }^{\mathrm{z}}$ IAbRQ and BHQ-1 are quencher molecules available from the manufacturer. 
Ten blossoms from each treatment were assessed after 3 days, and another 10 blossoms after 5 days. Each blossom was removed from the scintillation vial using sterile forceps. Disease symptoms were scored using a severity index $(0$, no necrosis; 1 , necrosis on the stigma and hypanthium; 2 , necrosis visible on the underside of the sepals, but not extending into the ovary; 3 , necrosis extends into the ovary, no farther than the widest point; 4, necrosis extends to the base of the ovary; 5, necrosis extends into the peduncle). Every second blossom was further processed in order to quantify surface bacterial populations (described below). The experiment was conducted three times using suspensions prepared from independent bacterial cultures.

Assessment of bacterial numbers on blossoms. After disease severity was assessed, the petals and peduncle were removed and the remaining tissue (ovary, hypanthium, stamens, stigma) was placed in a sterile $1.5-\mathrm{ml}$ microcentrifuge tube. One milliliter of Direct Plant Extraction Buffer (Agdia Inc., Elkhart, IN) was added to each tube. Tubes were mixed by vortexing briefly, placed in a water bath sonicator such that only the cap was not immersed, and sonicated for $3 \mathrm{~min}$ to dislodge bacterial cells. Plant tissue was removed with a sterile toothpick and discarded. Bacterial cells were concentrated 10 -fold by centrifuging the blossom wash at $13,000 \times g$ for $5 \mathrm{~min}$, decanting the supernatant, and resuspending the pellet in $100 \mu \mathrm{l}$ of DiPEB. This processed sample was used directly as the template for real-time PCR. This procedure was also conducted using uninoculated blossoms, and the resulting clean blossom wash was used as a negative control.

The DiPEB buffer used in this study has been licensed by Agriculture and Agri-Food Canada to Agdia Incorporated (Elkhert, IN). Until such time as the buffer becomes commercially available, small quantities can be made available to academic researchers for the purposes of repeating these results.

Statistical analysis. Regression analysis of standard curve data was conducted in SigmaPlot, version 8 (SPSS, Inc., Chicago, IL). All other data were analyzed using SAS (Statistical Analysis Systems 8.2; SAS Institute, Cary, NC). Disease severity index ratings from the competition assay were converted to a percent scale based on the actual surface area of the hypanthium and ovary that corresponds to the extent of visible necrosis that was associated with each disease rating $(0=0 \% ; 1=20 \% ; 2=48 \%$; $3=61 \% ; 4=82 \%$; and $5=100 \%$ ). Population data were logarithmically transformed (base 10) in order to produce normally distributed data suitable for further analysis. If a given pathogen species was not detected on a blossom, the population size was assigned a value of $2 \mathrm{CFU}$ in order to avoid undefined log functions or ratios of logs. Disease severity data and transformed population data were analyzed with the general linear model (PROC GLM) using the Tukey-Kramer mean separation test for multiple comparisons.

To assess whether competition occurred between E. amylovora and $E$. pyrifoliae, their growth on independent blossoms was compared with their growth on coinoculated blossoms. Each blossom inoculated with only E. amylovora was paired randomly with a blossom from the same replicate that had been inoculated with only E. pyrifoliae. The "relative growth performance" of each species was expressed as $\log$ (species 1 alone)/[log(species 1 alone $)+\log ($ species 2 alone $)]$, or $\log ($ species 1 in mixture $) /$ $[\log ($ species 1 in mixture $)+\log ($ species 2 in mixture $)]$.

For each species, relative growth performance alone was compared with relative growth performance in a mixture using a $t$ test with a Satterthwaite adjustment for unequal variances.

There was no significant difference between replicated experiments $(P>0.05)$; therefore, data from multiple replications were pooled. When data were not normally distributed $(P<0.05$ in a Kolmogorov-Smirnov test), the results of parametric tests and nonparametric tests were compared. In no case was the departure from normality sufficient to invalidate the parametric tests. All mean values are given as mean $\pm 95 \%$ confidence limits.

\section{RESULTS}

Specificity and sensitivity of duplex real-time PCR. The specificity of each set of probes and primers was tested using all bacterial strains and species listed in Table 1. The levansucrase gene $(l s c)$ was selected as the amplification target for E. amylovora because levansucrase activity, which mediates the extracellular breakdown of sucrose into glucose and levan, has been observed in E. amylovora but not in E. pyrifoliae $(9,11,18)$. Specific quantification of $E$. pyrifoliae was achieved with primers and a probe that amplify and detect a 77-bp region of the $h r p W$ gene. This gene is part of the hrp cluster, which is present on the chromosome of both E. amylovora and E. pyrifoliae, but which shows sufficient interspecies variation to permit reliable differentiation of E. pyrifoliae from E. amylovora. Using the Ea-lsc primers and probe, all E. amylovora strains were positive regardless of the presence or absence of the pEA29 plasmid. No cross reactions were observed with $E$. pyrifoliae strains or any other species. The $h r p W$ probe and primers detected all E. pyrifoliae strains as well as the Japanese Erwinia strains. This combination did not detect any $E$. amylovora strain or any other species. No change in cycle threshold $\left(\mathrm{C}_{\mathrm{T}}\right)$ values was observed in the presence of non-target species.

Fluorescence signals were regularly obtained from standardized samples containing as few as $20 \mathrm{CFU}$ of either E. amylovora or E. pyrifoliae in a $25-\mu \mathrm{l}$ reaction. This detection threshold occurred at an approximate $\mathrm{C}_{\mathrm{T}}$ value of 33 . Reaction efficiency, as calculated by the Stratagene Mx4000 software, was greater than $95 \%$.

Duplex standard curves for E. amylovora and E. pyrifoliae are shown in Figure 1. Concentrations higher than $5 \times 10^{6} \mathrm{CFU}$ per $25-\mu l$ reaction were not tested. For $E$. amylovora, the relationship between $\mathrm{C}_{\mathrm{T}}$ and initial quantity was linear across a 4.5-log range. For E. pyrifoliae, the relationship between $\mathrm{C}_{\mathrm{T}}$ and initial quantity was linear across a 5-log range. While detection, indicated by a fluorescence signal by 33 cycles, was reliable and for initial pathogen quantities above $20 \mathrm{CFU}$ per $25-\mu \mathrm{l}$ reaction, quantification of both pathogens was highly repeatable only for initial quantities greater than approximately $100 \mathrm{CFU}$ per reaction. The standard curves for both species are essentially identical; the slight differences between slope and intercept values were within the range of variation between replicate real-time PCR runs.

Standard curves were prepared from cells diluted in buffer that had been sonicated with uninoculated blossoms according to the sampling procedure used for the competition assays. The curves therefore correspond directly to initial cell numbers, and account for the presence of any PCR inhibitors that may be present in the

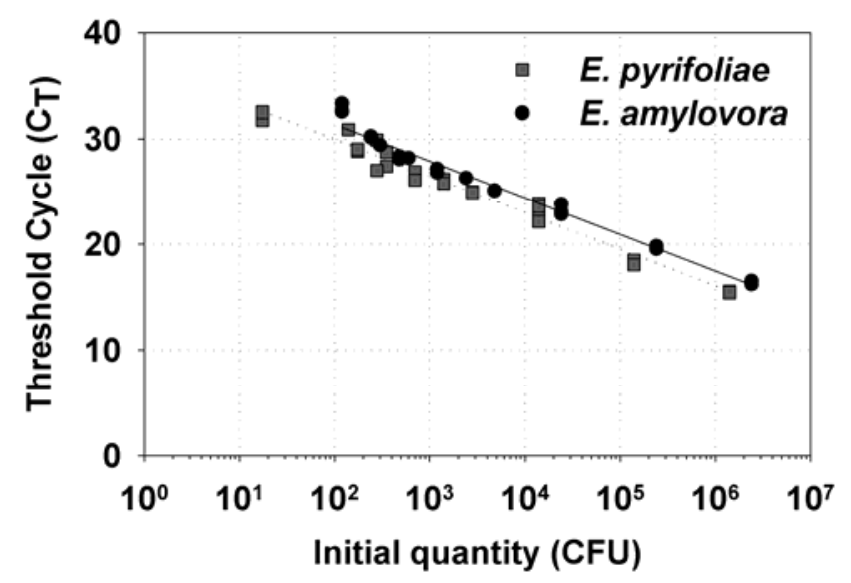

Fig. 1. Duplex standard curves for the quantitative detection of Erwinia amylovora and E. pyrifoliae. Known amounts of each pathogen were diluted in clean blossom wash. Quantification of E. amylovora (solid line) is given by $y=38.4-3.48 \log (x), R^{2}=0.975$. Quantification of E. pyrifoliae (dotted line) is given by $y=37.0-3.48 \log (x), R^{2}=0.973$. 
experimental samples. Since blossom infection occurs through the stigma and hypanthium, petals and peduncles were removed from the blossom, and bacteria were collected from the surfaces of the remaining structures. Removal of petals and peduncles improved the sensitivity of bacterial quantification (data not shown), presumably because it reduced the total volume of plant tissue, and thus the concentration of plant-derived PCR inhibitors. DNA extraction was not performed as part of sample preparation. The components of the wash buffer, along with the $5 \mathrm{~min}$ initial denaturation cycle at $95^{\circ} \mathrm{C}$, were sufficient to make the bacterial target DNA accessible for amplification.

There is no substantial difference between the standard curves produced by singleplex and duplex reactions (data not shown). For a given target species, duplex detection of a given cell concentration occurred about $0.5 \mathrm{C}_{\mathrm{T}}$ later than if the same sample was tested in a singleplex reaction. However, this difference is within the range of variation between replicate runs. Sensitivity did not differ between duplex and singleplex reactions.

Virulence of $\boldsymbol{E}$. amylovora and $\boldsymbol{E}$. pyrifoliae. Disease severity in blossoms treated with either E. amylovora or E. pyrifoliae

TABLE 3. The effect of initial inoculum size on disease severity in pear blossoms

\begin{tabular}{lcc}
\hline Time frame & $\begin{array}{c}\text { Initial inoculum size } \\
\text { (CFU/blossom) }\end{array}$ & $\begin{array}{c}\text { Percent disease } \\
(\text { mean } \pm 95 \% \mathrm{CL})^{\mathrm{z}}\end{array}$ \\
\hline $\begin{array}{l}\text { Across entire } \\
\text { experiment }\end{array}$ & 0 & $12.5 \pm 8.1 \mathrm{a}$ \\
& $1 \times 10^{2}$ & $38.8 \pm 8.1 \mathrm{~b}$ \\
& $1 \times 10^{4}$ & $48.2 \pm 8.2 \mathrm{~b}$ \\
& $1 \times 10^{6}$ & $64.4 \pm 8.2 \mathrm{c}$ \\
3 days elapsed since & 0 & $5.0 \pm 9.8 \mathrm{a}$ \\
inoculation & $1 \times 10^{2}$ & $13.4 \pm 9.8 \mathrm{ab}$ \\
& $1 \times 10^{4}$ & $23.3 \pm 9.9 \mathrm{~b}$ \\
& $1 \times 10^{6}$ & $46.0 \pm 9.8 \mathrm{c}$ \\
days elapsed since & 0 & $20.0 \pm 13.1 \mathrm{a}$ \\
inoculation & $1 \times 10^{2}$ & $64.2 \pm 13.1 \mathrm{~b}$ \\
& $1 \times 10^{4}$ & $73.1 \pm 13.3 \mathrm{~b}$ \\
& $1 \times 10^{6}$ & $82.8 \pm 13.3 \mathrm{~b}$ \\
\hline
\end{tabular}

${ }^{\mathrm{z}} \mathrm{CL}$, confidence limit. Disease severity is expressed as percent surface area that is visibly necrotic. Values are the means of two experiments, each with 10 blossoms per treatment. Within each time frame, means with the same letter are not significantly different $(P<0.05)$. alone was modeled in terms of (i) pathogen identity, (ii) initial inoculum size, and (iii) time elapsed since inoculation. Across the experiment as a whole, initial inoculum size and time elapsed since inoculation were significant predictors of disease severity ( $P<0.0001$ for both). There was also a significant interaction between these two factors $(P=0.0075)$. Specifically, initial inoculum size showed a significant $(P<0.0001)$, but qualitatively different, effect on disease severity at each of the two sampling times. Table 3 shows the results of a virulence assessment of $E$. amylovora and E. pyrifoliae on Bartlett pear blossoms. Blossoms showed no disease symptoms at the time of inoculation. In general, mean disease severity increased with increasing inoculum. Three days after inoculation, blossoms inoculated with $1 \times$ $10^{6} \mathrm{CFU}$ of either pathogen showed significantly more severe symptoms than blossoms that had received a smaller inoculum $(P<0.01)$. The differences between blossoms treated with $1 \times$ $10^{4} \mathrm{CFU}, 1 \times 10^{2} \mathrm{CFU}$, and $0 \mathrm{CFU}$ were less clear, as the difference between the 0 and $1 \times 10^{4}$ treatments was just significant at the 5\% level $(P=0.0496)$. By day 5 , however, the only significant difference in disease severity was between inoculated and uninoculated blossoms $(P<0.0001)$.

There was no significant effect of pathogen identity on disease severity across the experiment as a whole $(P=0.5182)$, or within any level of initial inoculum size at either sampling time (all $P>$ $0.4100)$.

Effect of initial pathogen ratio on disease severity. Figure 2 shows the overall effect of initial pathogen ratio on disease development, both 3 and 5 days after inoculation. Regardless of the time of observation, within each inoculum level, there was no significant difference between the severity of symptoms in blossoms treated with a 1:1 mixture of both pathogens and the severity of symptoms in blossoms treated with the same total amount of either species alone.

Relative population sizes of $\boldsymbol{E}$. amylovora and $\boldsymbol{E}$. pyrifoliae. Bartlett pear blossoms were inoculated with E. amylovora, E. pyrifoliae, or a 1:1 mixture of the two. Real-time PCR was used to determine the population sizes of both species after 3 days and again after 5 days. The logarithmically transformed population sizes were modeled in terms of (i) pathogen identity, (ii) whether the blossom had been inoculated with a single species or coinoculated with both, (iii) initial inoculum size, and (iv) time elapsed since inoculation. There was no difference in population sizes between days 3 and $5(P=0.5491)$ or among different levels of initial inoculum $(P=0.3414)$. Pathogen identity was sig-

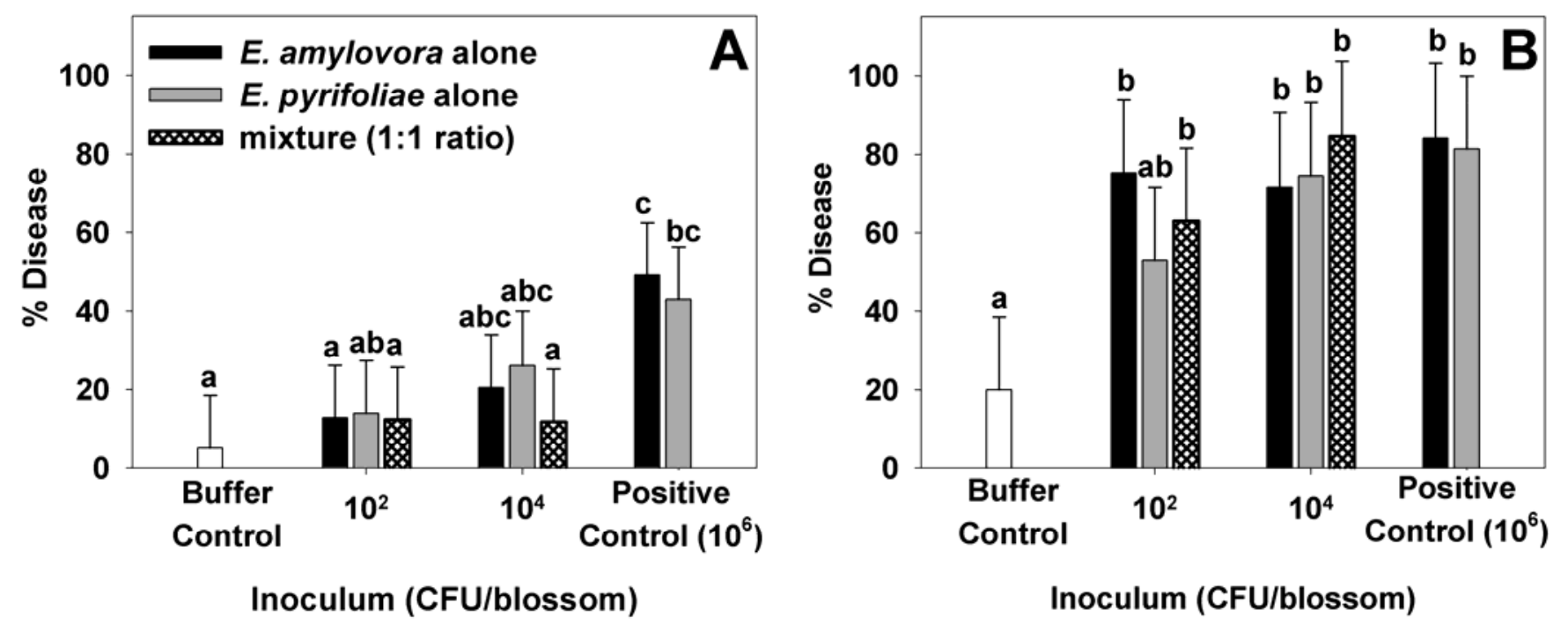

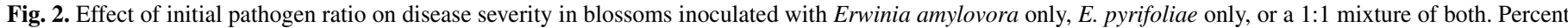

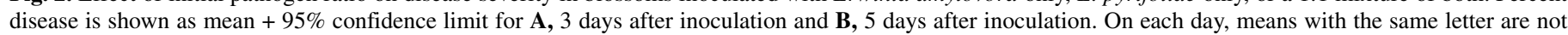
significantly different $(P<0.05)$. 
nificant $(P<0.0001)$, as was mixture $(P=0.0003)$, and there was a significant interaction between these two factors $(P=0.0021)$.

Figure $3 \mathrm{~A}$ shows the mean population sizes of $E$. amylovora and $E$. pyrifoliae on the pear blossoms, when present alone or together. In blossoms inoculated with only one of the two pathogen species, E. amylovora populations grew to a greater size than did E. pyrifoliae populations $(P=0.0002)$. E. amylovora populations were not significantly smaller on blossoms inoculated with both species than they were when $E$. pyrifoliae was absent $(P=$ $0.6688)$. However, E. pyrifoliae population sizes were significantly smaller in the presence of E. amylovora than when they grew alone on the blossoms. This difference is more clearly demonstrated by the relative growth performance index (Fig. 3B), where the growth of a species in either situation was expressed in relation to the total growth of both species. The relative contribution of E. amylovora to total bacterial growth was significantly greater $(P=0.0001)$, and the relative contribution of $E$. pyrifoliae was significantly less $(P=0.0001)$, on blossoms inoculated with both species than on blossoms inoculated with a single species.

\section{DISCUSSION}

There is currently a need for simple, sensitive methods of studying the in situ growth and interactions of microbial populations. E. amylovora, the causative agent of fire blight, is the focus of intensive research aimed at understanding and inhibiting its epiphytic and endophytic growth phases. E. pyrifoliae is very closely related to E. amylovora and causes a similar disease on Asian pear trees. In this study, a duplex real-time PCR method was developed that allows simultaneous identification and quantification of E. amylovora and E. pyrifoliae directly from blossom surfaces, independent of their cultivability. The application of this technique to an in situ competition assay then revealed that E. amylovora had a greater competitive fitness than E. pyrifoliae on Bartlett pear blossoms. This is the first time that the interactions of these two close relatives have been studied.

A supplemental outcome of this study was the production of new evidence about the relationships among E. amylovora, E. pyrifoliae, and Erwinia strains from Japan. The latter were isolated from Asian pear trees on Hokkaido. Initial studies suggested that these were very similar to E. amylovora (1), which agreed with a 1981 Japanese report. However, the subsequent identification of E. pyrifoliae as a distinct species from E. amylovora, despite many shared morphological, metabolic, and genetic simi- larities, has prompted a reassessment of that conclusion. The detection of the Japanese Erwinia isolates with the primers and probe designed for E. pyrifoliae in this study is further evidence that these isolates should not be considered variants of E. amylovora, but likely belong to E. pyrifoliae. This is supported by data from other studies, which indicate that these isolates are not identical to E. amylovora, and, in fact, resemble E. pyrifoliae more closely than E. amylovora $(14,15,18,26)$.

Most previous PCR methods for E. amylovora detection have been based on the pEA29 plasmid $(3,23,30,36)$; of the others $(2,25,38)$, only one was truly species-specific and targets a known chromosomal region (2). A chromosomal target was chosen for this study because of the emergence of E. amylovora strains in nature that lack pEA29 (24). For both E. amylovora and E. pyrifoliae detection, fluorescence signals were regularly obtained from standards containing as few as $20 \mathrm{CFU}$ per $25-\mu \mathrm{l}$ reaction $\left(\mathrm{C}_{\mathrm{T}}=\right.$ 33 ) and quantification was very reliable for cell concentrations as low as $100 \mathrm{CFU}$ per 25 - $\mu$ l reaction $\left(\mathrm{C}_{\mathrm{T}}=30\right)$. For the purposes of qualitative detection of these species on blossoms, samples yielding a $C_{T}$ value of 30 or less would be considered positive for the respective pathogen, while samples yielding a $C_{T}$ value between 30 and 35 may warrant retesting to confirm the presence of the target. During the population monitoring experiments described in this study, $\mathrm{C}_{\mathrm{T}}$ values less than 26 were very rarely obtained. Despite the fact that the primers and probes described here target single-copy chromosomal genes, the sensitivity of the method developed in this study is comparable to that achieved in a pEA29based real-time PCR assay for E. amylovora alone (36).

The blossom bioassay used for these experiments was based on the fact that primary infection by E. amylovora occurs through the reproductive organs (41). In blossoms treated with a single pathogen species, there was no apparent difference between the virulence of E. amylovora and E. pyrifoliae on Bartlett pear blossoms, despite the absence of levan production by E. pyrifoliae (18), and the association between levan-deficiency and reduced virulence in E. amylovora (9). No more than 100 cells of either pathogen were needed to cause fire blight symptoms in a single blossom, and there was no difference in the progression of symptoms resulting from inoculation with a given amount of either pathogen. However, the mean population size of E. pyrifoliae on these blossom surfaces was significantly smaller than the mean $E$. amylovora population size, which suggests that $E$. pyrifoliae does not grow as well as E. amylovora on Bartlett pear blossoms. This difference was not sufficient to hinder the infection process, which may

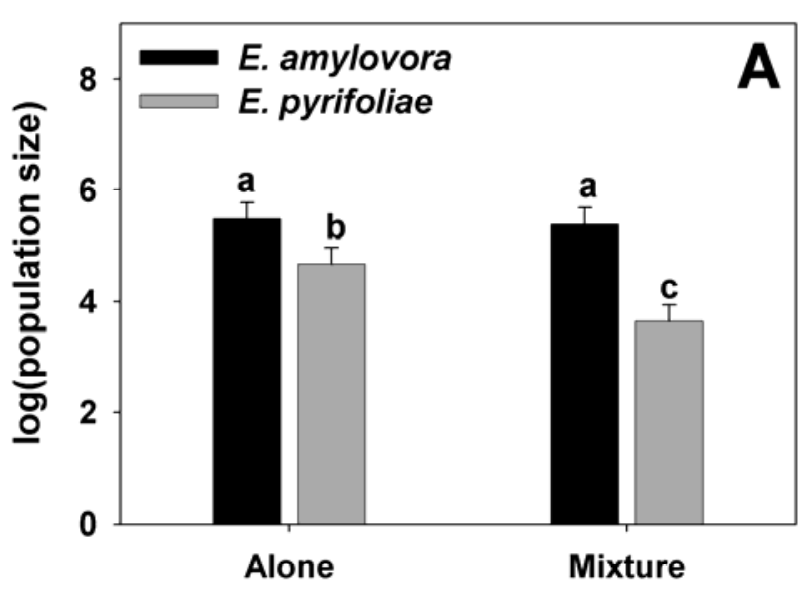

Growth Environment

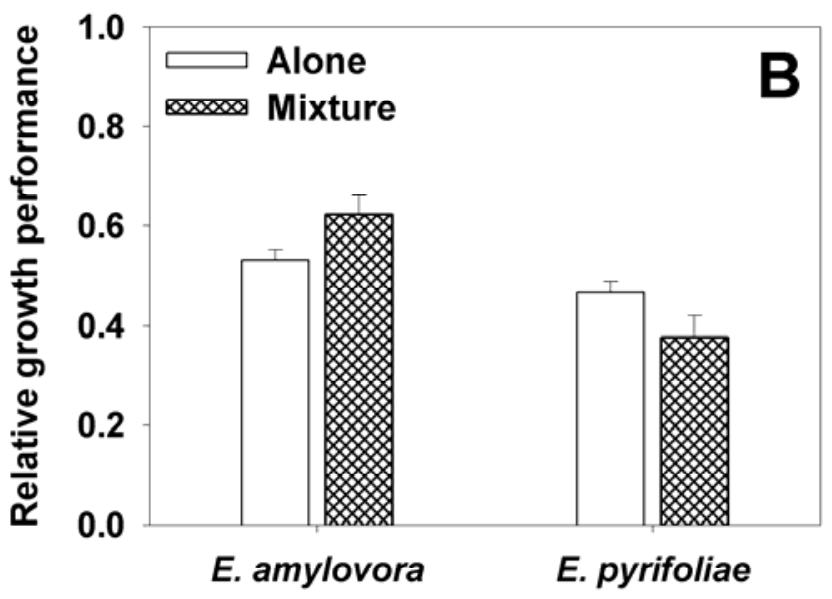

Pathogen

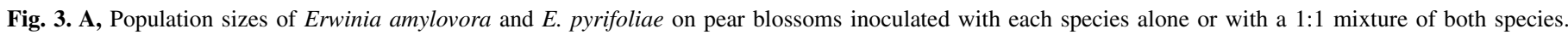

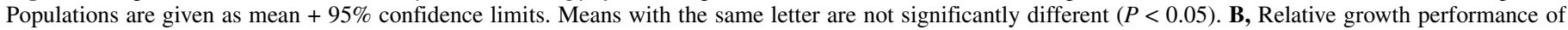

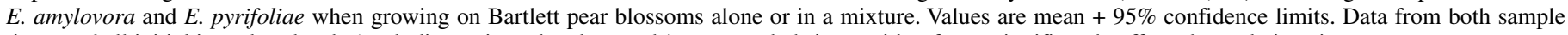
times and all initial inoculum levels (excluding uninoculated controls) were pooled since neither factor significantly affected population size. 
indicate that infection following inoculation of the hypanthium is associated with a threshold population size smaller than $4.7 \times 10^{4}$ CFU/blossom, which was the mean population of $E$. pyrifoliae in the absence of E. amylovora. Population sizes larger than $1 \times 10^{5}$ CFU/blossoms have previously been associated with E. amylovora infection of pear blossoms $(16,40)$. Those studies involved spray-inoculated blossoms where pathogen growth on the stigma would also be relevant to disease development, since bacteria colonizing the stigma tend to be washed down into the hypanthium prior to colonization. The slightly lower threshold population suggested by our study may be a real difference due to inoculation method, or may simply be a consequence of the different analytical methods used in each study.

Some necrosis was unexpectedly observed in the buffer-treated blossoms (Table 3, Fig. 2). Most blossoms showed no necrosis whatsoever, but four blossoms were completely necrotic by day 5 , probably due to natural infestation by a necrotizing pathogen. Not all were tested using the real-time PCR assay, but surface populations of E. amylovora were not detected from those that were. This, combined with the random pairing of blossoms for statistical analysis, makes it very unlikely that the larger E. amylovora populations are the result of the pathogen being present prior to experimental inoculations.

In blossoms treated with a 1:1 mixture of both E. amylovora and $E$. pyrifoliae, disease severity was not significantly different than in blossoms inoculated with either species alone. Clearly the presence of both species together neither amplifies nor inhibits their pathogenicity. What is not clear from these results is whether the two species are contributing equally to the production of disease, or whether one species out-competes the other to become dominant. Real-time PCR data revealed that the growth of E. amylovora on Bartlett pear blossoms was unaffected by the presence of an equal number of $E$. pyrifoliae cells. In contrast, the growth of E. pyrifoliae was negatively affected by E. amylovora and the population size of E. pyrifoliae relative to E. amylovora was significantly smaller when both species were present together than when they grew alone. This observation suggests that E. amylovora has greater competitive fitness on Bartlett pear blossoms. It is not known whether this simply represents differential success in the utilization of available nutrients and other resources, or whether any specific antagonism is involved. Since sucrose is abundant in the nectaries of host blossoms (4), it has been suggested that the extracellular breakdown of sucrose by levansucrase may contribute to nutrient utilization or to osmotic adaptation by E. amylovora (11). In the case of nutrient utilization, it is intracellular sucrose metabolism by the $s c r$ regulon, and not extracellular levansucrase activity, that is required for pathogenicity (5), but this does not eliminate the possibility that levansucrase activity might play a role in the differential success of cooccurring E. amylovora and E. pyrifoliae populations.

It would be interesting to test whether the relative fitness of these pathogens is the same on blossoms of Pyrus pyrifolia, or whether E. pyrifoliae is better adapted to Asian pear blossoms than E. amylovora. E. amylovora and E. pyrifoliae are not currently known to coexist in nature, but they are very closely related and have partially overlapping host ranges. It is generally accepted that E. amylovora is native to North America (6), but little is known about the evolutionary relationship between $E$. amylovora and E. pyrifoliae beyond the substantial genomic similarity. An understanding of how they behave when they are present together on different host species could shed light on their current distribution or potential distribution in the future. In light of the rapid spread of modern plant pathogens, it is certainly possible that these species could be introduced to the same regions in the future. Their relative fitness will influence the outcome of such introductions. It may also be informative to look for differences in this competitive interaction in blossoms following stigma inoculation versus hypanthium inoculation.
One of the major advantages of the primers and probes developed in this study is that they are compatible in a duplex reaction, allowing simultaneous, independent quantification of both species. This method is transferable to a field situation and has been successfully used to monitor E. amylovora populations in experimental orchards as part of a fire blight biological control study (21). The omission of a DNA extraction step makes this technique attractive in terms of time- and cost-savings, especially for field studies, which tend to rapidly generate a large number of samples.

The potential for simultaneous quantification of several target species is not limited to E. amylovora and E. pyrifoliae. The methods described here are also applicable to simultaneous monitoring of a pathogen and biocontrol agent (21). The primers and probes developed in this study are species-specific. Strain-specific real-time PCR has been used to monitor the population of an applied fire blight biocontrol agent, Pseudomonas fluorescens EPS62e (32). The combination of species-specific and strainspecific primers and probes could be used to study the relative contribution of an applied biocontrol agent to the total population of that species. Ultimately, since all primers and probes must function at the same reaction temperature, the applicability of multiplex real-time PCR to phytopathology, in general, and biological control, in particular, will depend on the availability of sufficient sequence data for probe and primer design.

\section{ACKNOWLEDGMENTS}

The first and second authors contributed equally to this work. We thank K. Geider (BBA, Germany) for providing the Japanese E. pyrifoliae strains, Ejp556 and Ejp557, and for generously assisting with the specificity testing involving those strains; S. V. Beer (Cornell University), G. W. Sundin (Michigan State University), M. M. Lopez (IVIA, Spain), L. Pusey (USDA), and D. Cupples (AAFC, Canada) for providing the indicated bacterial strains for use during specificity testing; and Cherry Lane Orchards (Vineland, Canada) as well as E. Barszcz, B. Kemp, B. Arbon (AAFC, Canada) for assistance in acquiring the budwood used for the competition assays. This work was supported by an Improved Farming Systems and Practices Initiative grant from Agriculture and Agri-Food Canada. S. M. Lehman was supported by a doctoral post-graduate scholarship from the Natural Sciences and Engineering Research Council of Canada.

\section{LITERATURE CITED}

1. Beer, S. V., Kim, J. H., Zumoff, C. H., Bogdanove, A. J., Laby, R. J., Tanii, A., Tamura, O., Gustafson, H. L., Momol, T., and Aldwinckle, H. S. 1996. Characterization of bacteria that cause "bacterial shoot blight of pear" in Japan. Acta Hortic. 411:179-181.

2. Bereswill, S., Bugert, P., Bruchmüller, I., and Geider, K. 1995. Identification of Erwinia amylovora by PCR with chromosomal DNA. Appl. Environ. Microbiol. 61:2636-2642.

3. Bereswill, S., Pahl, A., Bellemann, P., Zeller, W., and Geider, K. 1992. Sensitive and specie-specific detection of Erwinia amylovora by polymerase chain reaction-analysis. Appl. Environ. Microbiol. 58:35223526.

4. Bieleski, R. L. 1969. Accumulation and translocation of sorbitol in apple phloem. Aust. J. Biol. Sci. 22:611-620.

5. Bogs, J., and Geider, K. 2000. Molecular analysis of sucrose metabolism of Erwinia amylovora and influence on bacterial virulence. J. Bacteriol. 182:5351-5358.

6. Bonn, W. G., and van der Zwet, T. 2000. Distribution and economic importance of fire blight. Pages 37-53 in: Fire Blight, the Disease and Its Causative Agent, Erwinia amylovora. J. L. Vanneste, ed. CABI Publishing, Wallingford, UK.

7. Chiou, C.-S., and Jones, A. L. 1995. Molecular analysis of high-level streptomycin resistance in Erwinia amylovora. Phytopathology 85:710714.

8. Falkenstein, H., Bellemann, P., Walter, S., Zeller, W., and Geider, K. 1988. Identification of Erwinia amylovora, the fireblight pathogen, be colony hybridization with DNA from plasmid pEA29. Appl. Environ. Microbiol. 54:2798-2802

9. Geier, G., and Geider, K. 1993. Characterization and influence on virulence of the levansucrase gene from the fire blight pathogen Erwinia amylovora. Physiol. Mol. Plant Pathol. 42:387-404. 
10. Gill, J. J., Svircev, A. M., Smith, R., and Castle, A. J. 2003. Bacteriophages of Erwinia amylovora. Appl. Environ. Microbiol. 69:21332138.

11. Gross, M., Geier, G., Rudolph, K., and Geider, K. 1992. Levan and levansucrase synthesized by the fireblight pathogen Erwinia amylovora. Physiol. Mol. Plant Pathol. 40:371-381.

12. Holcomb, G. E. 1998. First report of fire blight on Indian Hawthorn cultivar Olivia in Louisiana. Plant Dis. 82:1402.

13. Ishimaru, C. A., Klos, E. J., and Brubaker, R. R. 1988. Multiple antibiotic production by Erwinia herbicola. Phytopathology 78:746-750.

14. Jock, S., and Geider, K. 2004. Molecular differentiation of Erwinia amylovora strains from North America and of two Asian pear pathogens by analyses of PFGE patterns and $h r p N$ genes. Environ. Microbiol. 6:480490.

15. Jock, S., Jacob, T., Kim, W.-S., Hildebrand, M., Vosberg, H. P., and Geider, K. 2003. Instability of short-sequence DNA repeats of pear pathogenic Erwinia strains from Japan and Erwinia amylovora fruit tree and raspberry strains. Mol. Genet. Genomics 268:739-749.

16. Johnson, K. B., Stockwell, V. O., McLaughlin, R. J., Sugar, D., Loper, J. E., and Roberts, R. G. 1993. Effect of antagonistic bacteria on establishment of honey bee-dispersed Erwinia amylovora in pear blossoms and on fire blight control. Phytopathology 83:995-1002.

17. Kim, W. S., Gardan, L., Rhim, S. L., and Geider, K. 1999. Erwinia pyrifoliae sp. nov., a novel pathogen that affects Asian pear trees (Pyrus pyrifolia Nakai). Int. J. Syst. Bacteriol. 49:899-905.

18. Kim, W. S., Hildebrand, M., Jock, S., and Geider, K. 2001. Molecular comparison of pathogenic bacteria from pear trees in Japan and the fire blight pathogen Erwinia amylovora. Microbiology 147:2951-2959.

19. Kim, W.-S., Jock, S., Paulin, J. P., Rhim, S. L., and Geider, K. 2001. Molecular detection and differentiation of Erwinia pyrifoliae and host range analysis of the Asian pear pathogen. Plant Dis. 85:1183-1188.

20. Kim, W.-S., Schollmeyer, M., Nimtz, M., Wray, V., and Geider, K. 2002. Genetics of biosynthesis and structure of the capsular exopolysaccharide from the Asian pear pathogen Erwinia pyrifoliae. Microbiology 148:4015-4024.

21. Lehman, S. M. 2008. Development of a bacteriophage-based biopesticide for fire blight. Ph.D. thesis. Brock University, St. Catharines, Canada.

22. Lindemann, J., and Suslow, T. V. 1987. Competition between ice nucleation-active wild type and ice nucleation-deficient deletion mutant strains of Pseudomonas syringae and P. fluorescens biovar I and biological control of frost injury on strawberry blossoms. Phytopathology 77:882886.

23. Llop, P., Bonaterra, A., Penalver, J., and Lopez, M. M. 2000. Development of a highly sensitive nested-PCR procedure using a single closed tube for detection of Erwinia amylovora in asymptomatic plant material. Appl. Environ. Microbiol. 66:2071-2078.

24. Llop, P., Donat, V., Rodriguez, M., Cabrefiga, J., Ruz, L., Palomo, J. L., Montesinos, E., and Lopez, M. M. 2006. An indigenous virulent strain of Erwinia amylovora lacking the ubiquitous plasmid pEA29. Phytopathology 96:900-907.

25. Maes, M., Garbeva, P., and Crepel, C. 1996. Identification and sensitive endophytic detection of the fire blight pathogen Erwinia amylovora with
23S ribosomal DNA sequences and the polymerase chain reaction. Plant Pathol. 45:1139-1149.

26. Matsuura, T., Shinohara, H., Inoue, Y., Azegami, K., Tshushima, S., Tsukamoto, T., and Mizuno, A. 2007. Erwinia isolates from the bacterial shoot blight of pear in Japan are closely related to Erwinia pyrifoliae based on phylogenetic analyses of gyrB and $r p o D$ genes. J. Gen. Plant Pathol. 73:53-58.

27. Maxson-Stein, K., McGhee, G. C., Smith, J. J., Jones, A. L., and Sundin, G. W. 2003. Genetic analysis of a pathogenic Erwinia spp. isolated from pear in Japan. Phytopathology 93:1393-1399.

28. McGhee, G. C., Schnabel, E. L., Maxson-Stein, K., Jones, B., Stromberg, V. K., Lacy, G. H., and Jones, A. L. 2002. Relatedness of chromosomal and plasmid DNAs of Erwinia pyrifoliae and Erwinia amylovora. Appl. Environ. Microbiol. 68:6182-6192.

29. McManus, P. S., and Jones, A. L. 1995. Genetic fingerprinting of Erwinia amylovora strains isolated from tree-fruit crops and Rubus spp. Phytopathology 85:1547-1553.

30. McManus, P. S., Jones, A. L., and Bonn, W. G. 1996. Detection of Erwinia amylovora by nested PCR and PCR-dot-blot and reverse blot hybridizations. Acta Hortic. 411:87-90.

31. Norelli, J. L., Jones, A. L., and Aldwinckle, H. S. 2003. Fire blight management in the twenty-first century. Plant Dis. 87:756-765.

32. Pujol, M., Badosa, E., Manceau, C., and Montesinos, E. 2006. Assessment of the environmental fate of the biological control agent of fire blight, Pseudomonas fluorescens EPS62e, on apple by culture and realtime PCR methods. Appl. Environ. Microbiol. 72:2421-2427.

33. Pusey, P. L. 1997. Crab apple blossoms as a model for research on biological control of fire blight. Phytopathology 87:1096-1102.

34. Rhim, S. L., Volksch, B., Gardan, L., Paulin, J. P., Langlotz, C., Kim, W.S., and Geider, K. 1999. Erwinia pyrifoliae, an Erwinia species different from Erwinia amylovora, causes a necrotic disease of Asian pear trees. Plant Pathol. 48:514-520.

35. Saad, A. T., Hanna, L., and Choueiri, E. 2000. Evaluation of streptomycin and oxytetracycline resistance of Erwinia amylovora populations in Lebanon. (Abstr.) Phytopathology 90(suppl.):S68.

36. Salm, H., and Geider, K. 2004. Real-time PCR for detection and quantification of Erwinia amylovora, the causal agent of fire blight. Plant Pathol. 53:602-610.

37. Schaad, N. W., Jones, J. B., and Chun, W. 2001. Laboratory guide for identification of plant pathogenic bacteria. American Phytopathological Society, St. Paul, MN.

38. Taylor, R. K., Guilford, P. J., Clark, R. G., Hale, C. N., and Forster, R. L. S. 2001. Detection of Erwinia amylovora in plant material using novel polymerase chain reaction primers. N.Z. J. Crop Hortic. Sci. 29:35-43.

39. Thomson, S. V., and Ockey, S. C. 2001. Sudden widespread appearance of streptomycin resistance in Erwinia amylovora in Utah. (Abstr.) Phytopathology 91(suppl.):S88.

40. Thomson, S. V., Schroth, M. N., Moller, W. J., and Reil, W. O. 1975. Occurrence of fire blight of pears in relation to weather and epiphytic populations of Erwinia amylovora. Phytopathology 65:353-358.

41. van der Zwet, T., and Keil, H. L. 1979. Fire blight: A bacterial disease of rosaceous plants. U.S. Department of Agriculture, Washington, DC. 